\title{
Investigating geothermal reservoir potential using numerical simulation
}

\author{
Mohamed Motir*, Ahmed El Banbi**, Mahmoud Abu El Ela***, Mohamed Samir****, \\ Sayed EITayeb*** and Sherif Haddara***** \\ * Petroleum Engineer, North Sinai Petroleum Company, Egypt \\ ** Professor of Petroleum Engineering and Chair of the Department, Department of Petroleum and Energy Engineering, The American \\ University in Cairo, Egypt \\ *** Professor of Petroleum Engineering, Faculty of Engineering, Cairo University, Egypt \\ **** Operations Manager, Sahara Oil and Gas Company, Egypt \\ ***** Former Minister of Petroleum and Mineral Resources, Egypt \\ **Corresponding Author : ahmed.elbanbi@aucegypt.edu
}

$\begin{array}{ll}\text { Submitted } & : 20 / 07 / 2020 \\ \text { Revised } & : 11 / 01 / 2021 \\ \text { Accepted } & : 20 / 01 / 2021\end{array}$

\begin{abstract}
Egypt depends on oil and gas for electricity generation (about 90\%). The remaining small percentage comes from the hydropower of the High Dam (about 8\%), the wind energy, and the solar cells. Therefore, it is important to adjust this unbalanced energy mix in Egypt. The continuous scientific research is the best way to try to solve this problem by studying the feasibility of using available renewable energy sources. Among these energies is the geothermal potential energy. However, it has not been exploited as a renewable source for power generation in Egypt yet. This study aims to determine the locations of reservoirs, which have high temperature gradient that can be suitable for implementing geothermal energy projects in Egypt. The study is executed using data of deep wells that are located in different regions to investigate the technical possibility of utilizing subsurface reservoirs for geothermal power generation pilot projects. The results indicate that the best reservoirs with high temperature gradient are located in the Western Desert and around the Gulf of Suez especially at Hammam Faraun and Ras Budran fields. These two locations have recorded reservoir temperatures of $100^{\circ} \mathrm{C}$ and $146^{\circ} \mathrm{C}$ at depths of $1150 \mathrm{~m}$ and $3800 \mathrm{~m}$, respectively. Simulation studies are conducted, and the results show that these formations can feed a power plant by $21,000 \mathrm{bbl} / \mathrm{day}$ of hot water at well head temperature ranging between $94^{\circ} \mathrm{C}$ and $105^{\circ} \mathrm{C}$ from a pilot project of two producers and one injector in Ras Budran (or four producers and two injectors in Hammam Faraun). Each pilot will be able to generate annual amount of electricity equal to 4,977 MWh through a binary cycle power plant. This proposed pilot project can be scaled up to generate additional electricity. Accordingly, application of this unfunded research recommendations can save hard currency and increase the national income.
\end{abstract}

Keywords: Geothermal energy; Hammam faraun formation; Ras budran field; Geothermal production well; Geothermal injection well. 


\section{INTRODUCTION}

The archeological finds prove that North American Indians utilized geothermal springs several thousand years ago (Stober \& Bucher, 2013). At that time, this renewable energy source was used directly in heating, cooking and bathing. However, the first industrial usage of the geothermal energy was in Italy in the $18^{\text {th }}$ century.

In 1922, the Americans constructed a geothermal power plant with a power capacity of $250 \mathrm{~kW}$. In 1946, they established geothermal heat pump. In 1960s, the first large scale geothermal power plant was constructed in San Francisco with a power capacity of 11 MW (Stober \& Bucher, 2013). Nowadays, USA has 60 geothermal power plants at 11 sites.

Figure 1 elucidates the geothermal power capacity worldwide in 2015 . The capacity of the existing plants ranges from 3450MW in USA to $1 \mathrm{MW}$ in Australia. It is noticed that only Ethiopia and Kenya in Africa have geothermal energy projects with power capacity of $7 \mathrm{MW}$ and $594 \mathrm{MW}$, respectively (Bertani, 2015).

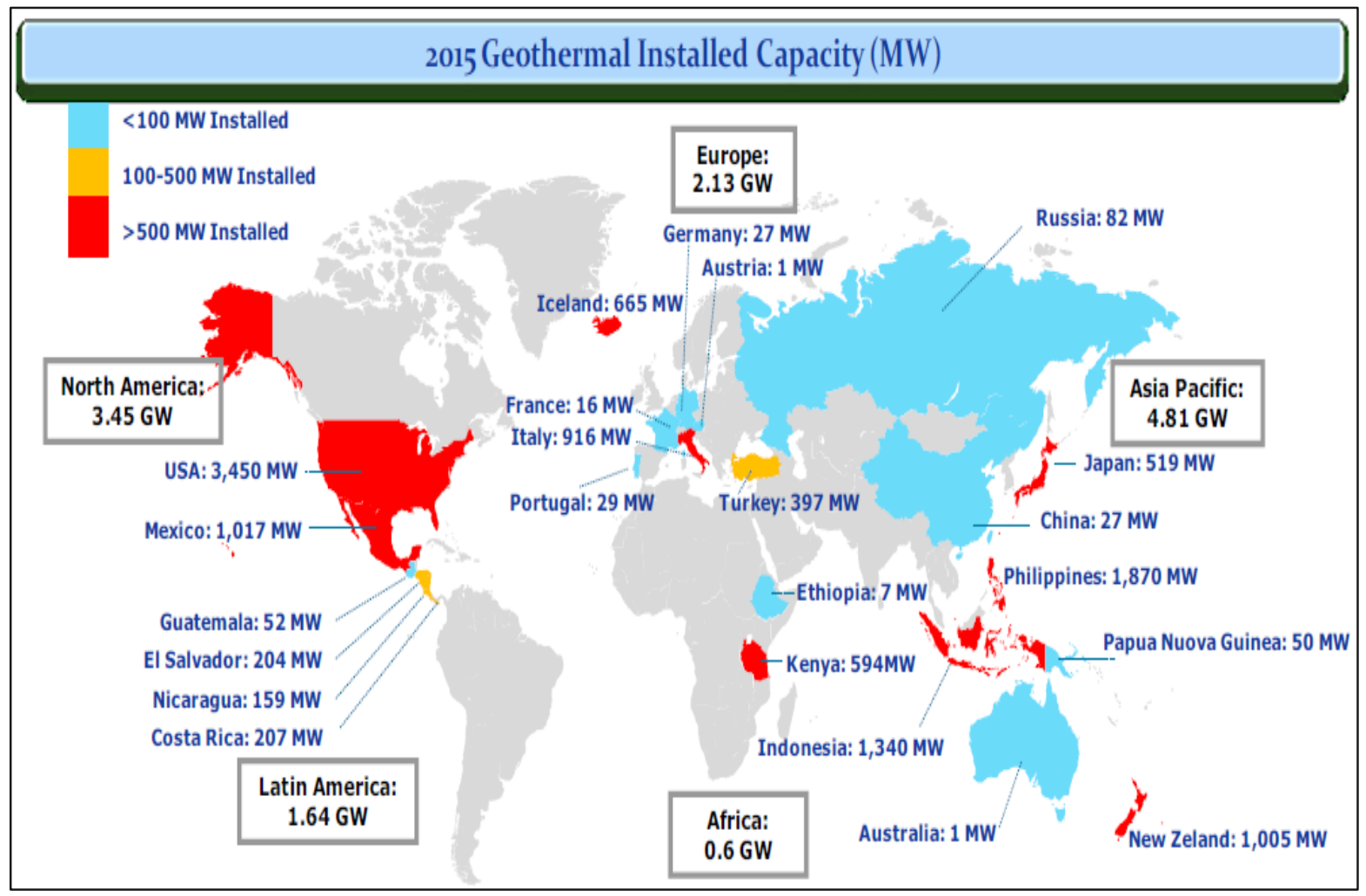

Figure 1: Geothermal power capacity map in 2015 (After Bertani, 2015).

Egypt has not used geothermal energy yet. The power generation in Egypt is highly dependent on oil and gas. More than $90 \%$ of the produced electricity is generated by using fossil fuels as shown in Table 1 (NREA, 2018). The remaining power sources (auxiliary energy sources) are provided by the hydropower (about $8 \%$ ), the wind energy $(1.3 \%)$ and solar cells $(0.0002 \%)$. The energy mix in Egypt should be adjusted to reduce the dependence on fossil fuels. 
Table 1: Statistics of electricity power generation in Egypt (NREA, 2018).

\begin{tabular}{|c|c|c|c|c|}
\hline Energy resources & $\begin{array}{c}\text { Installed capacity } \\
\text { (MW) }\end{array}$ & $\begin{array}{c}\text { Installed capacity } \\
\text { (\%) }\end{array}$ & $\begin{array}{c}\text { Energy } \\
\text { generation (GW } \\
\text { h) }\end{array}$ & $\begin{array}{c}\text { Energy } \\
\text { generation (\%) }\end{array}$ \\
\hline Fossil fuels & 38000 & 90.44 & 151606 & 90.96 \\
\hline Hydroelectric & 2832 & 6.70 & 12850 & 7.71 \\
\hline Wind & 1000 & 2.38 & 2200 & 0.32 \\
\hline Solar & 182 & 0.43 & 0.3 & 0.00018 \\
\hline Biomass & \multicolumn{4}{|c|}{ Mostly left unused } \\
\hline Geothermal & \multicolumn{2}{|c|}{100} & 166656 & 100 \\
\hline Total & 42014 & \multicolumn{2}{|c|}{} \\
\hline
\end{tabular}

The geothermal energy in Egypt can be considered at some scattered sites at the Western Desert and around the Gulf of Suez. Among the hottest known reservoirs in Egypt are Hammam Faraun and Ras Budran. These two sites can produce water with high wellhead temperature that can be used in electricity generation.

In this paper, we attempted to investigate the feasibility of constructing a geothermal pilot project in both Hammam Faraun and Ras Budran fields using a geothermal reservoir simulation program (HYDROTHERM). The tubing flow for both injectors and producers was modeled using a nodal analysis software program (PROSPER).

\section{GEOTHERMAL GRADIENT IN EGYPT}

The geothermal gradient is the rate of temperature change with respect to increasing depth in Earth's interior. As a rule, the crust temperature is rising with depth due to the heat flow from the much hotter mantle, away from tectonic plate boundaries. The temperature rises in about $25-30{ }^{\circ} \mathrm{C} / \mathrm{km}$ of depth near the surface in most of the world (Fridleifsson et al., 2008). Depending on the drilling depth, a distinction is made between deep geothermal energy (>400 m) and near-surface geothermal energy (<400 m) (Duffield \& Sass, 2003).

Geothermal gradient data in Egypt has been collected from available logs of existing oil and gas wells and from previous studies. The available data indicates that the calculated heat flow in the Gulf of Suez, West and East of River Nile, and North of Egypt is in the range of $40 \mathrm{~mW} / \mathrm{m}^{2}$ to $175 \mathrm{~mW} / \mathrm{m}^{2}$ (Morgan \& Swanberg, 1978).

The heat flow is in the range of $40 \mathrm{~mW} / \mathrm{m}^{2}$ to $45 \mathrm{~mW} / \mathrm{m}^{2}$ in the West of River Nile based on data from 128 oil wells. These values are considered low compared with the values in the Gulf of Suez area. The heat flow at East of River Nile (including Gulf of Suez) is measured with high values at several sites. It reaches $175 \mathrm{~mW} / \mathrm{m}^{2}$ at approximately $2 \mathrm{~km}$ away from the Red Sea coast (measured for Precambrian granitic gneiss). This might be attributed to local oxidation heating or water movement associated with a phosphate mineralized zone. 
The minimum estimation for the heat flow at the Gulf of Suez area ranges between $80 \mathrm{~mW} / \mathrm{m}^{2}$ to $100 \mathrm{~mW} / \mathrm{m}^{2}$. This means that the heat flow in the Gulf of Suez area is higher than the heat flow at the North of Egypt by approximately $30 \%$. The temperature gradients from the temperature logs all over Egypt are summarized in Table 2 (Morgan \& Swanberg, 1978; Lashin \& Al Arifi, 2010). It is clear that both of Hammam Faraun and Ras Budran areas recoded the highest temperature gradient $\left(45^{\circ} \mathrm{C} / \mathrm{km}\right.$ and $32^{\circ} \mathrm{C} / \mathrm{km}$, respectively). These two regions are furthered studied in this work to investigate their geothermal reservoir potential as pilot projects.

Table 2: Temperature gradients from temperature logs all over Egypt.

\begin{tabular}{|c|c|c|c|}
\hline Area & Location & Temp. gradient* $\left({ }^{\circ} \mathrm{C} / \mathbf{k m}\right)$ & Remarks \\
\hline Eastern of Egypt & $\begin{array}{l}\text { Gulf of Suez oil wells at } \\
\text { western part }\end{array}$ & $26.7+/-5.5$ (78 wells) & Recorded $110 \mathrm{BHT}^{* *}$ \\
\hline North Egypt & Mediterranean Sea & $14-22$ & Heat flow $30-45 \mathrm{~mW} / \mathrm{m}^{2}$ \\
\hline \multirow{2}{*}{ Western of Egypt } & Northern desert oil wells & $20.6+/-2(128$ wells $)$ & Recorded 248 BHT \\
\hline & Abu Tartur phosphate & $74.4+/-6$ (8 wells $)$ & \\
\hline \multirow{8}{*}{ Sinai Peninsula } & $\begin{array}{l}\text { Eastern part of the Gulf } \\
\text { of Suez }\end{array}$ & 22 to 44 & 149 oil wells \\
\hline & Hammam Faraun & 45 & Hot spring $80-150 \mathrm{~m}$ \\
\hline & Ras Budran field & 32 & $\begin{array}{l}\text { BHT } 150^{\circ} \mathrm{C} \text { at } 3900 \mathrm{~m} \\
\text { for Nubia sand } \\
\text { formation. }\end{array}$ \\
\hline & Ayun Musa & 32 & $\begin{array}{l}\text { Coal exploration } 400 \text { to } \\
450 \mathrm{~m}\end{array}$ \\
\hline & Ras Misalla & 27 & Six oil wells \\
\hline & Abu El Darag & 25 & Five oil wells \\
\hline & Matarma and Sudr & 32 to 35 & $\begin{array}{l}26 \text { oil wells at depth } \\
\text { from } 133 \text { to } 1741 \mathrm{~m}\end{array}$ \\
\hline & Conoco oil field & 23 to 27 & $\begin{array}{l}\text { Six oil wells at depth } \\
2900 \text { to } 4200 \mathrm{~m}\end{array}$ \\
\hline
\end{tabular}

*Temp. gradient: Temperature gradient

** BHT: Bottom Hole

Temperature

\section{STUDY METHODOLOGY}

The following methodology and steps have been used to execute this work:

a) Review for the regional geothermal gradient data in Egypt and selection of two sites for possible pilot projects: This step relied on both literature data and well logging data. The two selected sites (Hammam 
Faraun and Ras Budran) were found to have considerable potential for designing pilot projects. The selection was based on available subsurface temperature data, existence of potential aquifers of reasonable thickness and sufficient porosity and permeability at reasonable depth.

b) Data collection: The relevant data (e.g., depth, formation thickness, porosity, permeability, and subsurface temperature) were collected for the selected two sites.

c) Development of simulation model to identify the subsurface design parameters: A geothermal simulator was used to build simulation models for the two sites. The subsurface reservoir simulation was developed to determine the injector/producer pattern, well distances, and water injection/production rates. In addition, sensitivity analysis was performed for optimization.

d) Development of vertical lift performance model to identify the heat and fluid flow in the tubing: A flowin-pipes software program was used to model the flow and temperature profiles of both injectors and producers. The software was mainly used to determine the surface water temperature at desired rates.

\section{DATA COLLECTION AND ANALYSIS}

Table 3 presents summary for the main reservoir data of (1) the Limestone formation at Hammam Faraun geothermal field and (2) the Nubia sandstone formation at Ras Budran geothermal field. The geological information of Hammam Faraun and Ras Budran geothermal fields demonstrate that these fields are liquid-dominated systems, with accessible thermal water temperature about $100^{\circ} \mathrm{C}$ for Hammam Faraun field and around $146^{\circ} \mathrm{C}$ for Ras Budran field. The high temperature in Ras Budran field is viewed as economically useful for a pilot project.

The geothermal potential in thermal megawatt is evaluated for Hammam Faraun hot spring for power creation and other low-temperature purposes. The evaluated geothermal potential in Hammam Faraun is seen to be 12.4 MW, which is viewed as economic and useful for building a small geothermal power plant.

The temperature, thermal conductivity, heat flow and heat capacity profiles versus depth of Hammam Faraun field are presented in Figure 2 (Lashin A. 2015). However, the formation temperature and thermal conductivity versus depth of Ras Budran field are shown in Figure 3 (Morgan et al., 1985). The analysis of the temperature profiles assigns medium geothermal gradient for the two fields (geothermal gradient of $45^{\circ} \mathrm{C} / \mathrm{km}$ for Hammam Faraun field and $32^{\circ} \mathrm{C} / \mathrm{km}$ Ras Budran field). The reservoir and the thermal data of the two fields have been used to develop the geothermal simulation.

Table 3. Summary for the main reservoir data of Hammam Faraun and Ras Budran geothermal fields.

\begin{tabular}{|l|c|c|c|}
\hline Field & Hammam Faraun & Ras Budran & \multirow{2}{*}{ Source of the Data } \\
\cline { 1 - 3 } Productive zone & $\begin{array}{c}\text { Limestone } \\
\text { formation }\end{array}$ & $\begin{array}{c}\text { Nubia sandstone } \\
\text { formation }\end{array}$ & Logging \\
\hline Reservoir temperature, ${ }^{\circ} \mathbf{C}$ & 100 & 146 & Logging \\
\hline Depth, $\mathbf{m}$ & 1150 & 3800 & Estimated from normal gradient \\
\hline Bottom hole pressure, $\mathbf{p s i}$ & 1636 & 5405 & Available information \\
\hline Permeability $(\mathbf{K}), \mathbf{m d}$ & 80 & 100 & Available information \\
\hline Porosity $(\boldsymbol{\varphi}), \mathbf{\%}$ & 0.15 & 0.25 & Normal thickness in the area \\
\hline Thickness, $\mathbf{m}$ & 100 & 100 & \\
\hline
\end{tabular}




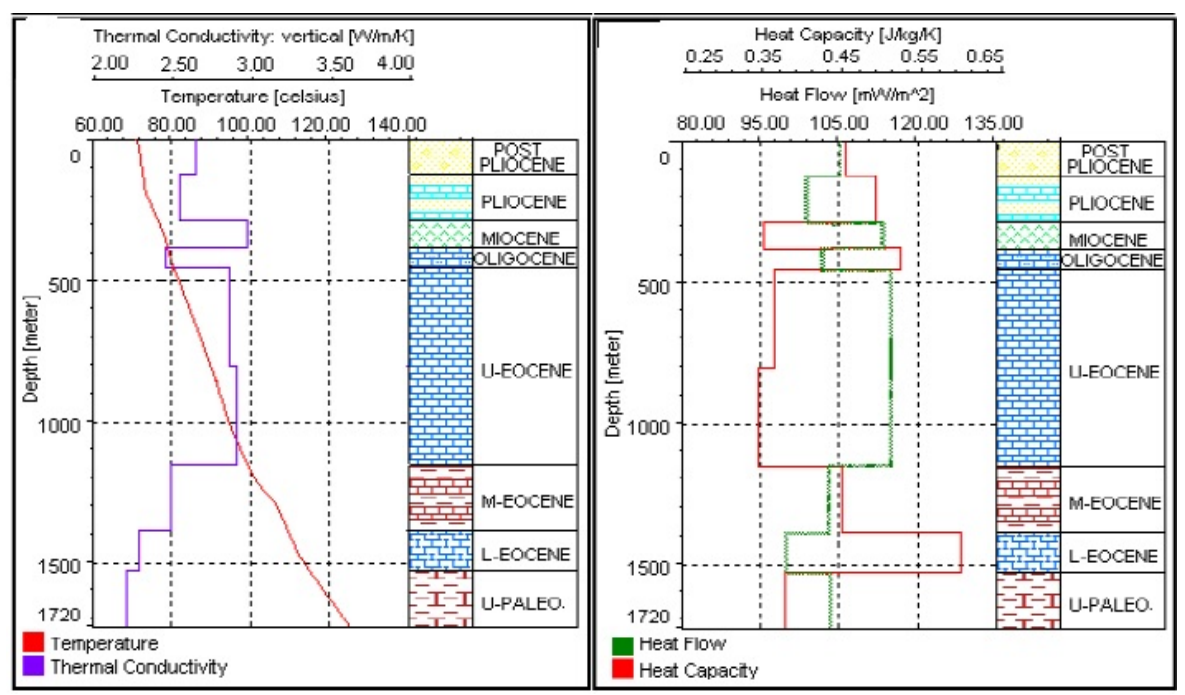

Figure 2: Temperature, thermal conductivity, heat flow, and heat capacity profiles of Hammam Faraun field (After Lashin, 2015).

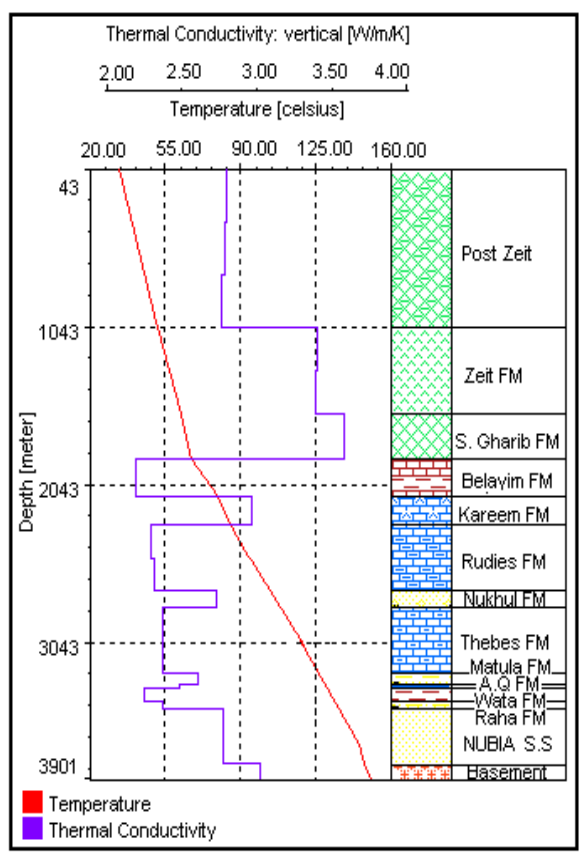

Figure 3: Formation temperature and thermal conductivity of Ras Budran field (After Morgan et al., 1985).

\section{SIMULATION MODEL}

In this study, the HYDROTHERM simulator was used to identify (1) the number of the injectors and producers, (2) the distance between the wells, and (3) the water injection and production rates from each well. This computer program is a geothermal reservoir simulator. It can be used to simulate multi-phase ground water flow and heat 
transport in the porous and permeable rock. It can handle fluid pressure up to 10,000 psi and temperature range of $0^{\circ} \mathrm{C}$ to $1200^{\circ} \mathrm{C}$ in three dimensions (Kipp et al., 2008). The input reservoir data include porosity, permeability, temperature, pressure, thermal conductivity, and fluid density. The reservoir is divided into several blocks/grids and layers. The temperature of each grid block is solved versus time, taking into consideration the temperature of injected and produced water. The simulator provides the heat distribution in the reservoir at each time interval.

\subsection{Modeling of the Geothermal Resource for Hammam Faraun Reservoir}

Hammam Faraun geothermal hot spring field shows that this field has a place of moderate to high temperature system. The accessible thermal water temperature of Hammam Faraun is $100^{\circ} \mathrm{C}$ at depth of $1150 \mathrm{~m}$. The HYDROTHERM simulator was used to model the geothermal reservoir at Hammam Faraun as shown in Figure 4. The model included 1 injector and 2 producers. The results of this model gave good possibility of applying a reasonable geothermal project application when optimum design parameters were selected such as: wells pattern, well head temperature and flow rate. The flow rate and the well head temperature are used as a feed for the turbine system to generate electricity.

The simulator provides temperature distribution for each grid block between the injector and the producers in Hammam Faraun limestone formation. It should be highlighted that the temperature distribution is obtained at each time step. The temperature distribution at certain time steps can therefore be plotted (e.g., after 10, 20, 30, 40, and 50 years). Moreover, the water injection flow rate is also calculated at the injector which is located as shown in Figure 4.

The temperature profile between the injector and producers is plotted for every geothermal simulation run. The injection and production rates were varied at every assumed distance between the injector and producers. Figure 5 shows the temperature profile between the injector and producers at injection rate of $10,000 \mathrm{bbl} / \mathrm{day}$. The figure shows that the temperature increases as water travels through the reservoir. However, the water would essentially reach the reservoir temperature $\left(100^{\circ} \mathrm{C}\right)$ at a distance of $450 \mathrm{~m}$. Then, the water temperature inside the reservoir is stabilized.

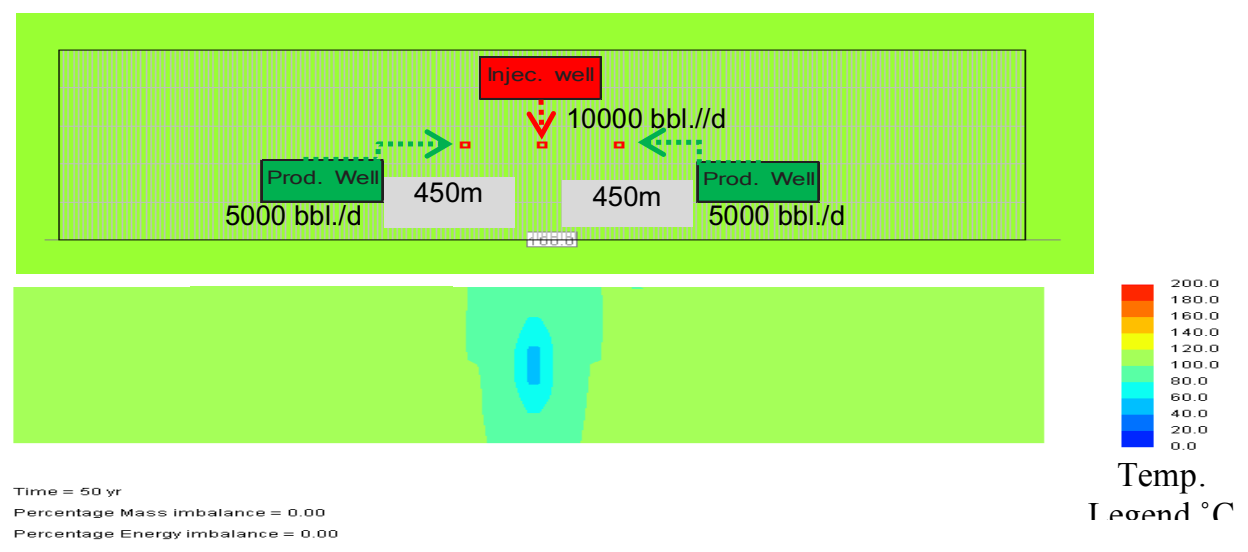

Time $=50$ years

Percentage Mass Imbalance $=0.0$

Percentage Energy Imbalance $=0.0$

Injec well: Injector

Prod. well: Producer

Figure 4: Schematic of the geothermal reservoir simulation model of Hammam Faraun (1 injector and 2 producers). 


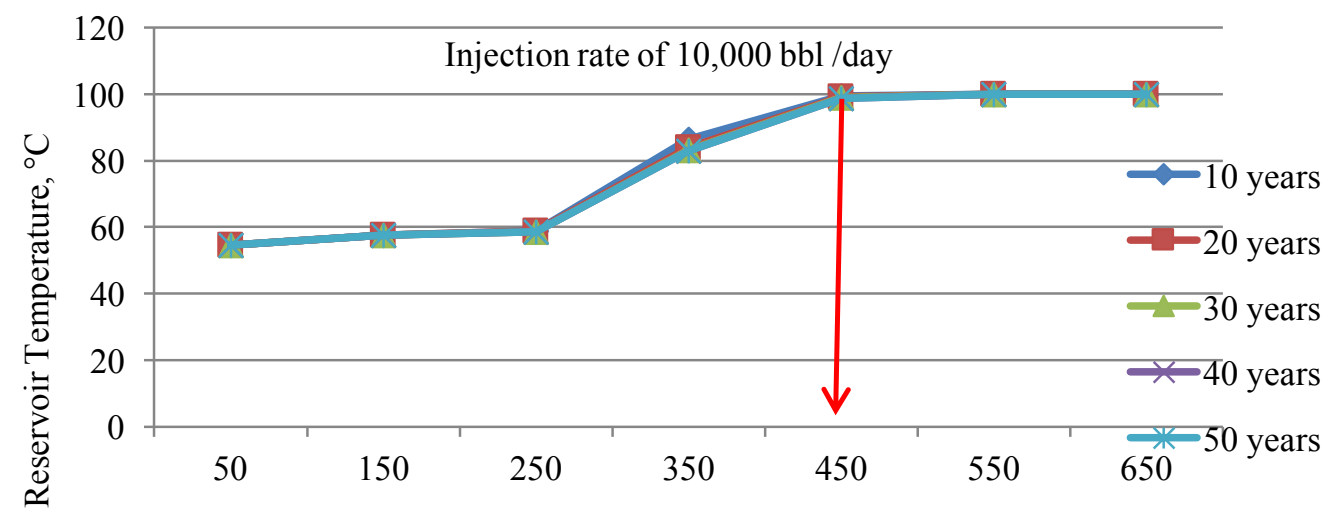

Figure 5: Temperature distribution between the injector and producers at injection rate of 10,000 bbl/day with several time intervals inside Hammam Faraun field.

PROSPER software was used to predict the optimum wellhead temperature and flow rate (User Manual of PROSPER, 2010). The intersection between the vertical lift performance (VLP) curve and the inflow performance relationship (IPR) curve shows that the optimum well flow rate is $5003 \mathrm{bbl} /$ day as shown in Figure 6 . This flow rate can be obtained by using Electrical Submersible Pump (ESP) with discharge pressure of 2040 psi and production tubing of 4.5 inch (inside diameter) as shown in Table 4.

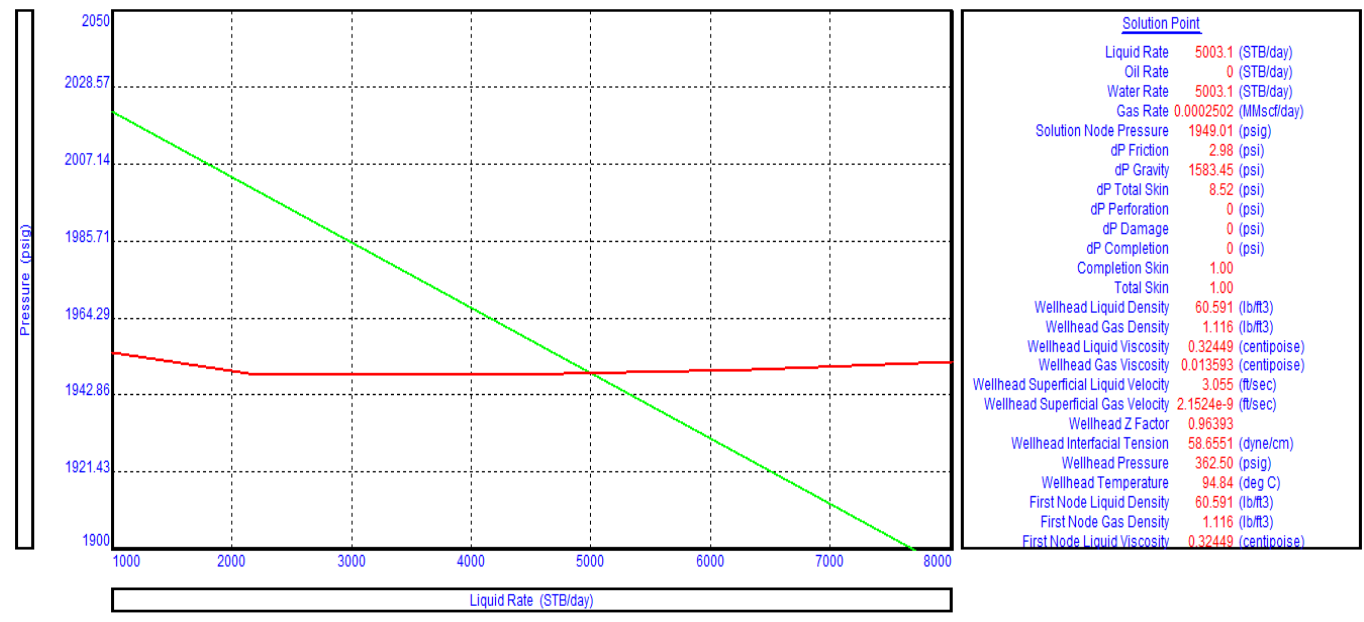

Figure 6: Intersection between the IPR curve and the VLP curve for producer at Hammam Faraun.

Table 4: Results of the vertical lift performance through production well at Hammam Faraun.

\begin{tabular}{|c|c|c|c|c|c|c|c|}
\hline $\begin{array}{c}\text { Depth, } \\
\mathrm{m}\end{array}$ & $\begin{array}{c}\text { Temperature, } \\
{ }^{\circ} \mathrm{C}\end{array}$ & $\begin{array}{c}\text { WHP*, } \\
\mathrm{psig}\end{array}$ & $\begin{array}{c}\text { WHT**, } \\
{ }^{\circ} \mathrm{C}\end{array}$ & $\begin{array}{c}\text { Rate, } \\
\text { bbl/day }\end{array}$ & $\begin{array}{c}\text { BHP***, } \\
\text { psig }\end{array}$ & $\begin{array}{c}\text { Pump discharge. } \\
\text { pressure, psi }\end{array}$ & $\begin{array}{c}\text { Tubing inside } \\
\text { diameter, inch }\end{array}$ \\
\hline 1150 & 100 & 362.5 & 94.84 & 5003 & 1636 & 2040 & 4.5 \\
\hline
\end{tabular}

* WHP: Wellhead Pressure

** WHT: Wellhead Temperature

*** BHP: Bottom Hole Pressure 
It should be highlighted that changing the production flow rates has impact to the well head temperature. The wellhead temperature increases with increasing the amount of the produced water at surface. Figure 7 shows the relation between the liquid flow rates and the wellhead temperatures. At the optimum flow rate of $5003 \mathrm{bbl} / \mathrm{day}$, the wellhead temperature will be $94.84^{\circ} \mathrm{C}$. This high temperature can improve the net power output.

In another study, surface geothermal pilot plant was designed to produce annual output of $4977 \mathrm{MWh}$ for power capacity of $531 \mathrm{~kW}$ (Abd El Aziz, 2017). This pilot plant requires water flow rate of about 21,000 bbl/d at temperature of about $100^{\circ} \mathrm{C}$ as a feed stream. Accordingly, Hammam Faraun site can provide the required feed stream for this pilot plant using four producers and two injectors (each producer can provide water with about $5003 \mathrm{bbl} /$ day at temperature of about $94.84^{\circ} \mathrm{C}$.).
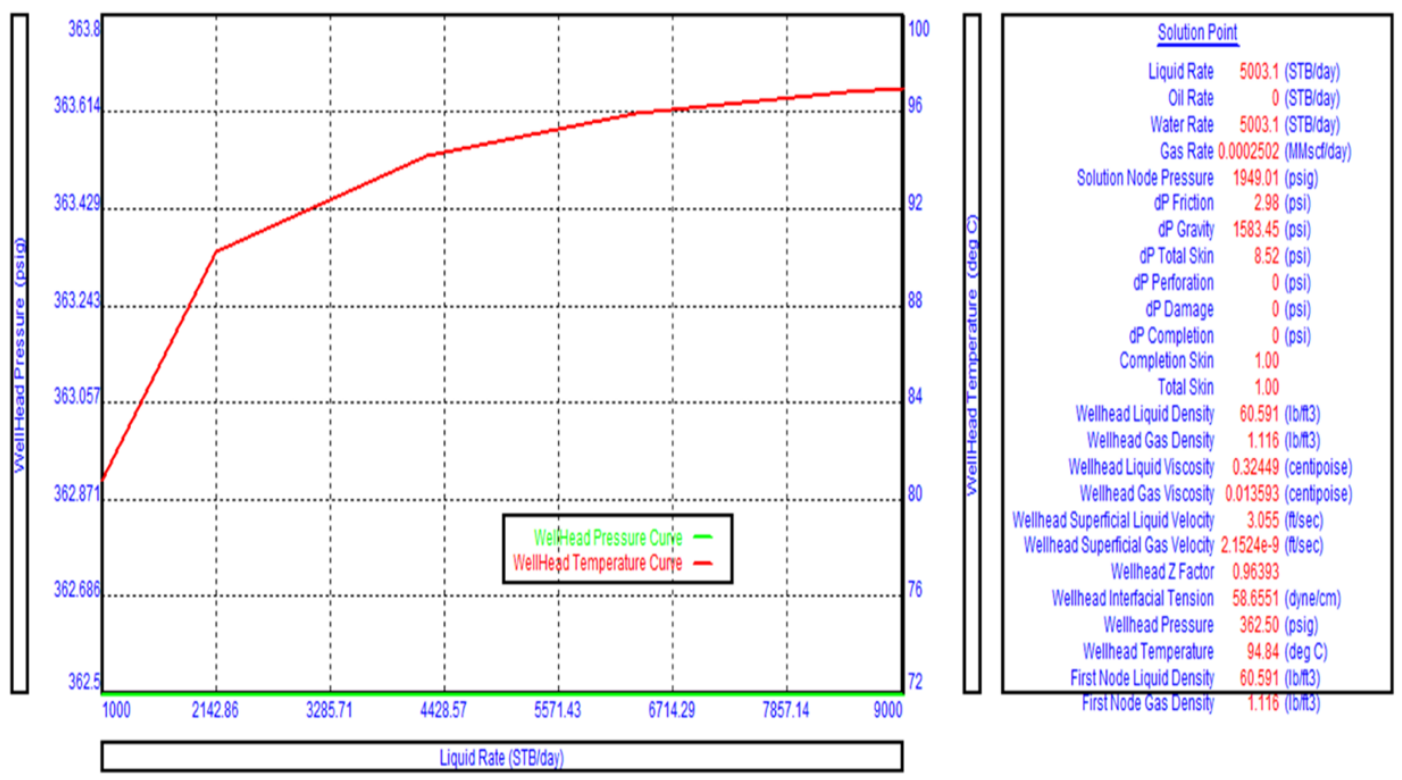

Figure 7: Liquid rate with well head temperature for producer at Hammam Faraun.

\subsection{Modeling of Geothermal Resource in Ras Budran Reservoir}

The Ras Budran Nubia sandstone formation shows that this reservoir has a place of moderate to hightemperature system. The accessible thermal water temperature for Ras Budran is $146^{\circ} \mathrm{C}$ at $3800 \mathrm{~m}$. the HYDROTHERM simulator was used to model the geothermal reservoir at Ras Budran as shown in Figure 8 . The model included 1 injector and 2 producers. The results of this model gave also good possibility of applying a reasonable geothermal project application when optimum design parameters were selected such as: wells pattern, well head temperature and flow rate. The flow rate and the well head temperature are used as a feed for the turbine system to generate electricity.

The simulator was used to provide the temperature distribution for every grid block in the Ras Budran model and at every time step. The water injection flow rate at the injector location shown in Figure 8 was also identified.

The geothermal reservoir simulator was used to optimize the water injection and production flow rates and identify the optimum distance between the injector and producers. Figure 9 shows the temperature distribution between the injector and producers at optimum injection rate of 20,600 bbl/day. This temperature distribution between the injector and producers is shown for time steps at 10, 20, 30, 40, and 50 years. The figure shows that the 
temperature increases as water travels through the reservoir. However, the water would essentially reach the reservoir temperature $\left(146^{\circ} \mathrm{C}\right)$ at a distance of $650 \mathrm{~m}$. Then, the water temperature inside the reservoir is stabilized.
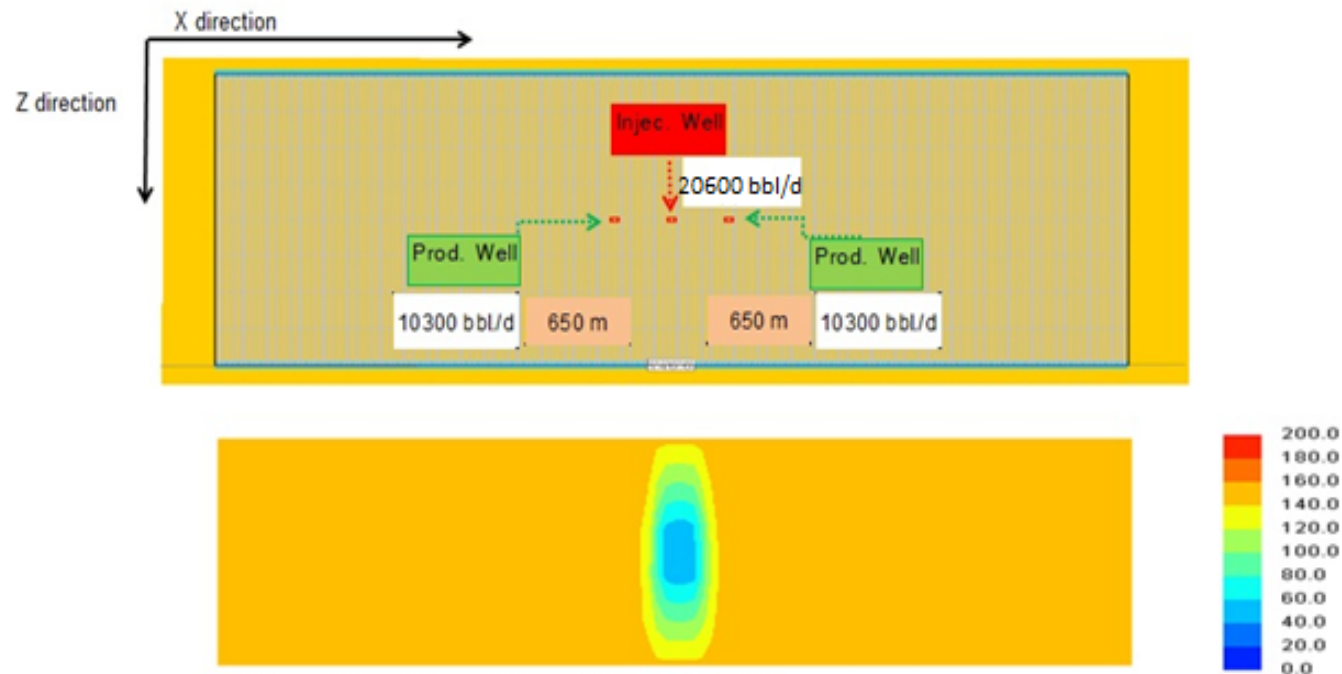

Time $=50$ years

Percentage Mass Imbalance $=0.0$

Injec well: Injector

Percentage Energy Imbalance $=0.0$

Prod. well: Producer

Temp. Legend ${ }^{\circ} \mathrm{C}$

Figure 8: Schematic for geothermal reservoir simulation model of Ras Budran Nubia sandstone reservoir (1 injector and 2 producers).

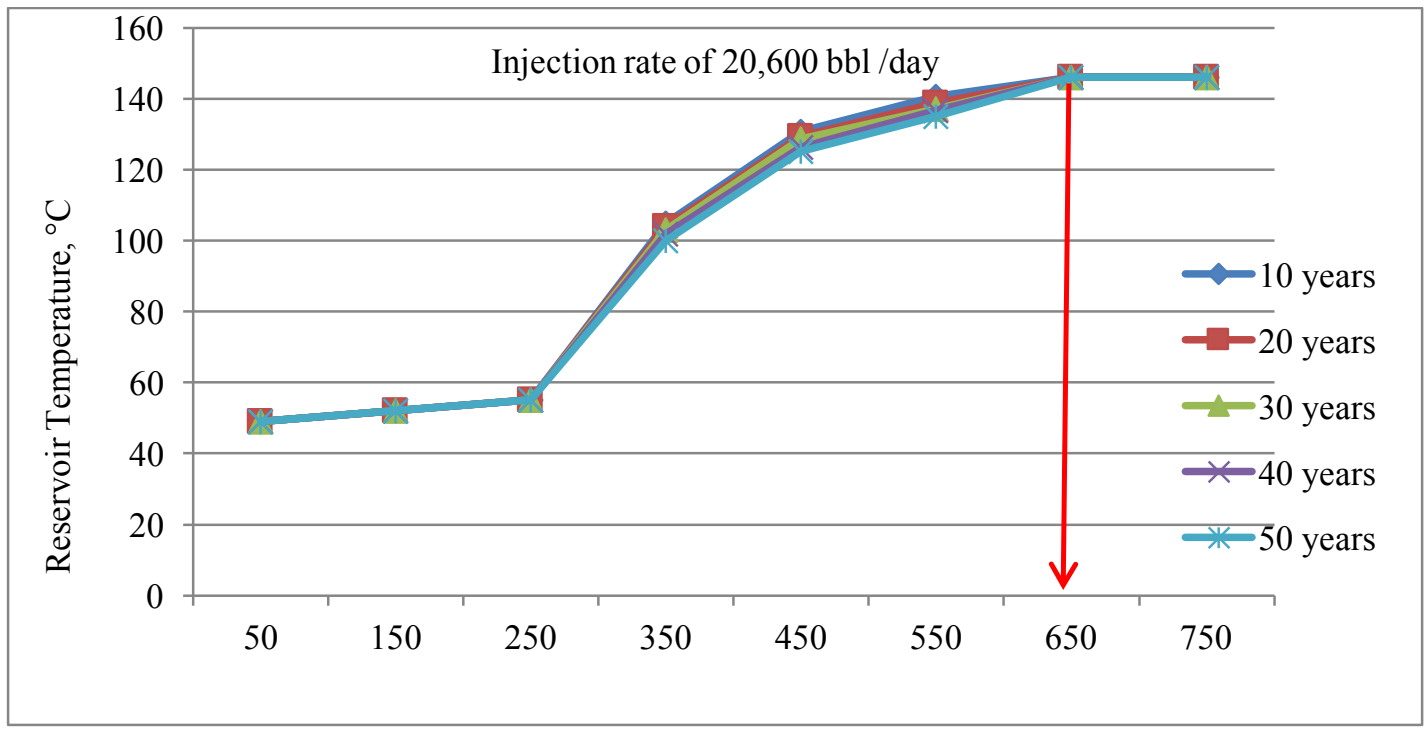

Figure 9: Temperature distribution between the injector and producers at injection rate of 20,600 bbl/d with several time intervals inside Ras Budran Nubia sandstone reservoir. 
PROSPER software was used to predict the optimum wellhead temperature and flow rate. The intersection between the vertical lift performance (VLP) curve and the inflow performance relationship (IPR) curve shows that the optimum well flow rate is $10,371 \mathrm{bbl} /$ day as shown in Figure 10. This flow rate can be obtained by using Electrical Submersible Pump (ESP) with discharge pressure of 5,565 psi and production tubing of 4.5 inch (inside diameter) as shown in Table 5 .

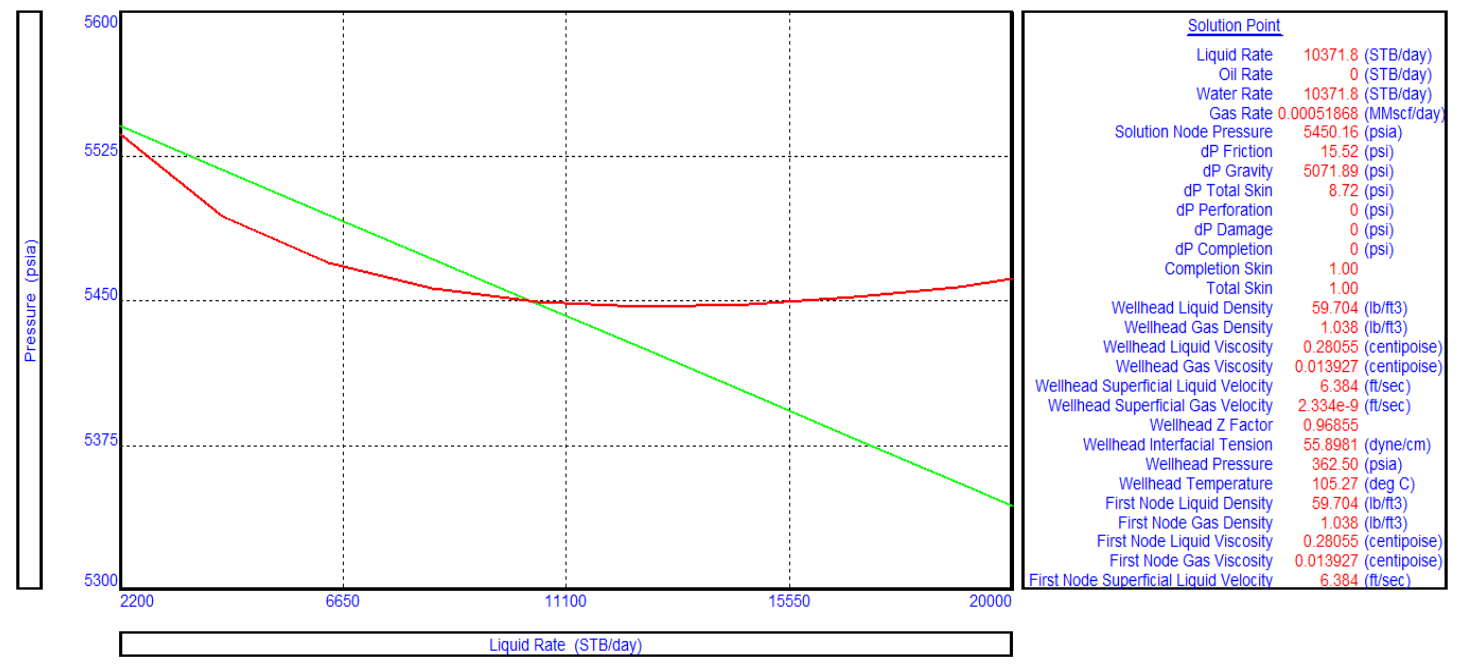

Figure 10: Intersection between the IPR curve and the VLP curve for producer at Ras Budran.

Table 5: Results of the vertical lift performance through production well at Ras Budran.

\begin{tabular}{|c|c|c|c|c|c|c|c|}
\hline $\begin{array}{c}\text { Depth, } \\
\mathrm{m}\end{array}$ & $\begin{array}{c}\text { Temperature, } \\
{ }^{\circ} \mathrm{C}\end{array}$ & $\begin{array}{c}\text { WHP*} \\
\mathrm{psig}\end{array}$ & $\begin{array}{c}\text { WHT* } \\
{ }^{*},{ }^{\circ} \mathrm{C}\end{array}$ & $\begin{array}{c}\text { Rate, } \\
\text { bbl/day }\end{array}$ & $\begin{array}{c}\text { BHP** } \\
*, \mathrm{psig}\end{array}$ & $\begin{array}{c}\text { Pump discharge. } \\
\text { pressure, psi }\end{array}$ & $\begin{array}{c}\text { Tubing inside } \\
\text { diameter, inch }\end{array}$ \\
\hline 3800 & 146 & 362.5 & 105 & 10371 & 5405 & 5565 & 4.5 \\
\hline
\end{tabular}

* WHP: Wellhead Pressure

** WHT: Wellhead Temperature

*** BHP: Bottom Hole Pressure

Figure 11 shows the relation between the liquid flow rates and the wellhead temperatures. It is clear that the wellhead temperature increases with increasing the amount of the produced water at surface. At the optimum flow rate of $10,371 \mathrm{bbl} /$ day, the wellhead temperature will be $105.27^{\circ} \mathrm{C}$. This high temperature can improve the net power output. With such conditions, the proposed surface geothermal pilot plant (the pilot plant which can produce annual output of $4977 \mathrm{MWh}$ for power capacity of $531 \mathrm{~kW}$ using water flow rate of about 21,000 bbl/d at temperature of about $100^{\circ} \mathrm{C}$ as a feed stream - (Abd El Aziz, 2017)) can be operated using two producers and one injector from Ras Budran site (each producer can provide water with about $10,371 \mathrm{bbl} /$ day at wellhead temperature of about $105.27^{\circ} \mathrm{C}$ ). 

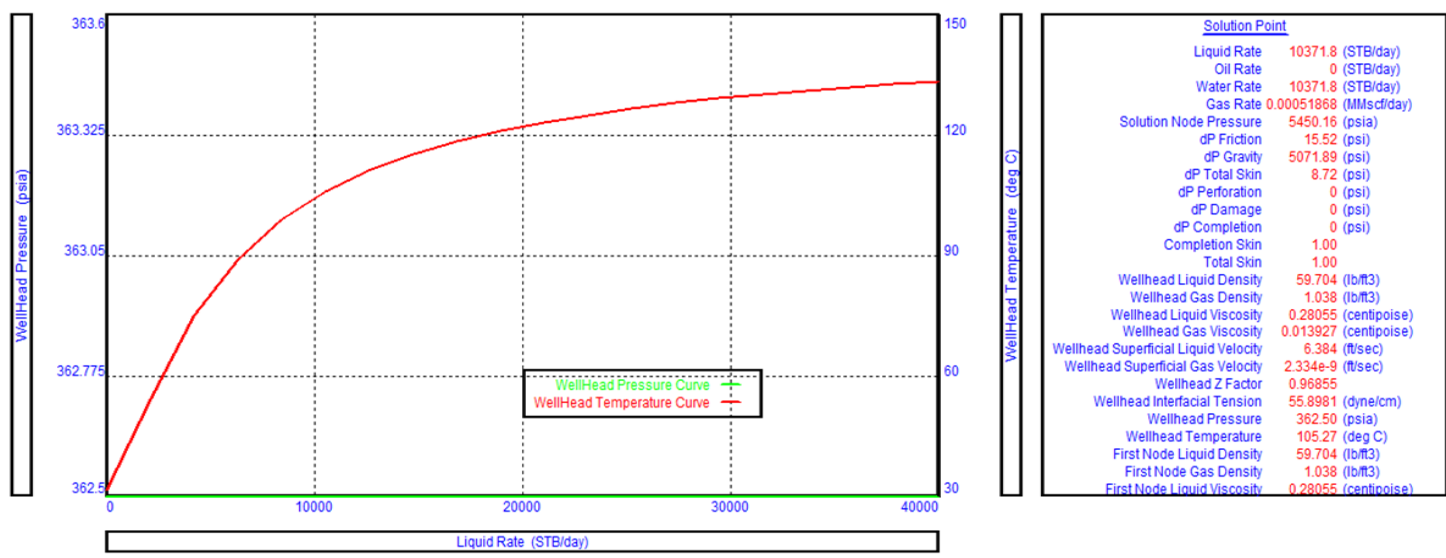

Figure 11: Liquid rate with well head temperature for producer at Ras Budran.

\section{DISCUSSION}

The geothermal energy is a renewable source of energy that can be utilized for electricity generation. It is restricted to certain sites where it can be applied. When a country is blessed with potential geothermal energy sources, they can be utilized to reduce dependency on other conventional sources such as fossil fuels. When other energy sources are used for electricity generation, the geothermal energy can be used to save fossil fuel costs.

In the two potential sites investigated above, the focus was on the subsurface feasibility. However, several recommendations for the design of the surface facilities should be considered during the execution of the pilot projects. These recommendations include (1) the use of coated tubulars in water injection wells and water/steam production wells to conserve heat, (2) maximization of cost savings by utilizing existing wells to reduce the cost of drilling new wells (well integrity needs to be tested before a decision like this is made as explained by Schon in 2015), and (3) preheating of the injected water (using available solar energy) to around $60^{\circ} \mathrm{C}$ to minimize the tendency of scale formation and damage inside the injection wells.

\section{CONCLUSIONS}

This study investigated the subsurface feasibility of two sites in Egypt for potential geothermal projects. Based on the results of this study, the following conclusions can be made:

1. A methodology to screen sites for potential geothermal projects is developed. The methodology depends on the availability of reasonable geothermal gradient at sites and the presence of the underground water aquifers that can be used for the geothermal applications.

2. Using the simulation and modelling techniques is important to design potential sites. The main design considerations include wells spacing, injection rates, production rates, and well completions.

3. Subsurface system design for proposed geothermal energy project was developed for both the limestone formation of Hammam Faraun site and the Nubia sandstone of Ras Budran site.

4. The Ras Budran field is better than Hammam Faraun field due to the higher temperature and flow rate that can be produced at the wellhead. This high temperature can improve the net power output. 
5. The design showed that the proposed surface geothermal pilot plant (the pilot plant which can produce annual output of $4977 \mathrm{MWh}$ for power capacity of $531 \mathrm{~kW}$ using water flow rate of about 21,000 bbl/d at temperature of about $100^{\circ} \mathrm{C}$ as a feed stream) can be operated by using either:

a. Two producers and one injector from Ras Budran site (each producer can provide water with about $10,371 \mathrm{bbl} /$ day at wellhead temperature of about $\left.105.27^{\circ} \mathrm{C}\right)$, or

b. Four producers and two injectors from Hammam Faraun site (each producer can provide water with about $5003 \mathrm{bbl} /$ day at temperature of about $94.84^{\circ} \mathrm{C}$.).

6. Egypt has potential of the geothermal energy particularly around the Gulf of Suez. If some of these proposed geothermal projects are implemented, energy mix in Egypt can benefit significantly.

\section{ACKNOWLEDGMENT}

The authors would like to thank the Mining Studies and Research Center (MSRC - Faculty of Engineering, Cairo University, Egypt) for their support and providing the idea of this study. This unfunded research work is an outcome of the cooperation protocol between the Egyptian General Petroleum Corporation (EGPC) and the MSRC.

\section{REFERENCES}

Abd El Aziz, H. 2017. Techno-Feasibility Study for Developing a Geothermal Power Plant. M.Sc. thesis Cairo University, Giza, Egypt.

Bertani, R. 2015. Geothermal Power Generation in the World 2010-2014 Update Report. Proceedings of the World Geothermal Congress. Melbourne, Australia.

Duffield, W. A. \& Sass, J. H. 2003. Geothermal Energy—Clean Power from the Earth's Heat. U.S. Geological Survey. Circular 1249, Reston, Virginia.

Fridleifsson, I. B., Bertani, R., Huenges, E., Lund, J. W., Ragnarsson, A. \& Rybach, L. 2008. The Possible Role and Contribution of Geothermal Energy to the Mitigation of Climate Change. Proceedings of the IPCC Scoping Meeting on Renewable Energy Sources (pp. 59-80). Luebeck, Germany.

Kipp, K.L., Hsieh, P.A. \& Charlton, S.R. 2008. Guide to the Revised Ground-Water Flow and Heat Transport Simulator: HYDROTHERM - Version 3. Techniques and Methods Series (Series 6-A25), U.S Geological Survey. Reston, Virginia, USA. DOI:10.3133/tm6A25

Lashin, A. 2015. Geothermal Resources of Egypt: Country Update. Proceedings of the World Geothermal Congress. Melbourne, Australia.

Lashin, A. \& Al Arifi, N. 2010. Some Aspects of the Geothermal Potential of Egypt. Proceedings of the World Geothermal Congress, Bali, Indonesia.

Morgan, P., Boulos, F. K., Hennin, S. F., EL-Sherif, A. A., EL-Sayed, A. A., Basta, N. Z. \& Melek, Y. S. 1985. Heat Flow in Eastern Egypt: The Thermal Signature of a Continental Breakup. Journal of Geodynamics 4 (1-4):107- 131.

Morgan, P. \& Swanberg, C.A. 1978. Heat Flow and the Geothermal Potential of Egypt. Pure and Applied Geophysics Journal 117:213-226.

NREA. 2018. Annual Report of the Egyptian New and Renewable Energy Authority (NREA). Ministry of Electricity and Renewable Energy, Egypt.

Schon, J. 2015. Basic Well Logging and Formation Evaluation. $1^{\text {st }}$ Edition. ebook at bookboon.com. 
Stober, I. \& Bucher, K. 2013. History of Geothermal Energy Use. In: Stober, I. \& Bucher, K. Geothermal Energy: From Theoretical Models to Exploration and Development. pp.15-24. Springer, Verlag Berlin Heidelberg.

User Manual of PROSPER (Version 11.5). 2010. IPM-Single Well Model Overview. Petroleum Experts Limited. Scotland, United Kingdom. 